\title{
AGGLOMERATION AND LOCATION DECISION OF FOREIGN DIRECT INVESTMENT (FDI) IN INDONESIA
}

\author{
(Aglomerasi dan Penentuan Lokasi Penanaman Modal Asing (PMA) di Indonesia) \\ Agustina* and David Flath** \\ *Directorate of Licensing Services, Deputy of Investment Service, \\ Indonesia Investment Coordinating Board, \\ Jl. Gatot Subroto No. 44, Jakarta Selatan, DKI Jakarta 12190 \\ Email: agustina.simarmata88@gmail.com \\ **College of Economics, Ritsumeikan University, Japan, 1 Chome-1-1 Nojihigashi, \\ Kusatsu, Shiga 525-8577, Jepang. Email: david.flath@gmail.com
}

Naskah diterima: 14 November 2019

Naskah direvisi: 26 November 2019

Naskah diterbitkan: 31 Desember 2019

\begin{abstract}
Abstrak
Penanaman modal asing (PMA) dapat mempercepat pertumbuhan ekonomi yang luar biasa, bahkan di negara-negara berkembang. PMA dapat menyediakan sumber daya keuangan, transfer teknologi, meningkatkan praktik dan keterampilan organisasi dan manajerial, dan memberikan akses ke pasar internasional. Pemerintah Indonesia telah menyadari bahwa PMA dapat memberikan kontribusi yang signifikan terhadap pembangunan ekonomi negara. Paper ini bertujuan untuk mengukur kepentingan relatif dari berbagai jenis aglomerasi untuk penentuan lokasi PMA di sektor manufaktur di Indonesia. Data ini dianalisis dengan model multinomial logit di mana variabel dependen adalah pilihan lokasi. Paper ini meneliti faktor-faktor penentu PMA baru (greenfield) di sektor manufaktur di Pulau Jawa, Indonesia. Penelitian ini menggunakan data tingkat mikro dari izin prinsip yang tidak dipublikasikan dari Badan Koordinasi Penanaman Modal Indonesia (BKPM). Penelitian ini menguji dari 23 kabupaten di Pulau Jawa yang menerima PMA di sektor manufaktur dalam lima tahun terakhir. Hasil dari temuan ekonomi agglomerasi (baik milik asing dan perusahaan domestik) menunjukkan dampak yang signifikan dan positif namun kecil. Variabel-variabel lain, termasuk fasilitas, dan kondisi pasar tenaga kerja-secara anomali dengan upah minimum yang lebih tinggi-menunjukan hasil yang lebih penting dibandingkan aglomerasi. Karena efek aglomerasi yang kecil, hal ini berarti bahwa ekonomi aglomerasi bukanlah faktor penentu dalam menarik PMA. Investor asing yang baru tidak hanya mencari kabupaten di mana pabrik asing atau domestik telah berada tetapi juga mempertimbangkan hal-hal lain seperti kepadatan jalan dan ketersediaan tenaga kerja.

Kata kunci: ekonomi aglomerasi, industri, ekonomi regional, multinomial logit
\end{abstract}

\begin{abstract}
Foreign direct investment (FDI) may precipitate remarkable economic growth, even in developing countries. FDI can provide financial resources, transfer technology, improve organizational and managerial practices and skills, and afford access to international markets. This paper aims to measure the relative importance of the different types of agglomeration for location decision of FDI in the manufacturing sector in Indonesia. These data are analyzed with a multinomial logit model where the dependent variable is the choice of location. It examines the determinant factors of new (greenfield) foreign direct investment in the manufacturing sector in Java Island, Indonesia. This study used unpublished micro-level data of principle licenses from the Indonesia Investment Coordinating Board (IICB), which examine 23 counties of Java Island that received manufacturing FDI in the last five years. The finding is agglomeration economies in production (both foreign-owned and domestic firms) show a significant and positive but small impact. Other variables, including facilities, and labor market conditions-anomalously in that a higher minimum wage-matter as much or more than an agglomeration of production. Because the agglomeration effect is small, it means that agglomeration economies are not the detemining factor in attracting FDI. The new foreign investors not only seek counties in which foreign or domestic plants have already located but also consider other things such as the density of roads and the availability of labor.
\end{abstract}

Keywords: agglomeration economies, manufacturing, regional economic activity, multinomial logit

\section{INTRODUCTION}

The distribution of Foreign Direct Investment (FDI) in Indonesia has shown that most of the firms are concentrated in Java Island, and generally, FDI manufacturers consider the relative profitability and specific advantages and the basic needs of FDI industry are the agglomeration of labor infrastructure, kind of industry and country of origin of FDI. This study aims to measure the relative importance of the different types of agglomeration for the location decision of
FDI in Indonesia. It examines determinant factors of FDI in the manufacturing sector in Java Island, Indonesia, 2013-2017, using the latest data from the Indonesia Investment Coordinating Board (IIBC).

Indonesia has sought to attract FDI. Indeed, the attraction of FDI has become an important element in the country's development strategy. One of the main reasons Indonesia needs foreign investors is because its net exports are low and its domestic consumption absorbs most of the nation's aggregate 
output (Primadhyta, 2017). But the provision of infrastructure to support FDI could strain the already limited financial resources of the government. The government has, therefore, sought ways to attract foreign investment without expending government funds. As one example of this, in 2007, Indonesia enacted a new law of investment, to simplify the investment licensing process, with an aim to increase foreign investment in the country.

Indonesia has attracted investors from many countries and is becoming more integrated with the global economy. As potential investors consider Indonesia, they seek to identify locations that could maximize their profit or minimize their cost. As we will see, the distribution of FDI across regions of Indonesia is highly imbalanced. Between 1996 and 2017 (see Table 1), 71.77 percent of the total FDI inflow went to Java Island, and 72.29 percent of the total number of foreign projects were located in Java. Other foreign-owned firms were located in the outer islands. The imbalanced distribution of foreign investment in Indonesia means that most FDI is focused in the big cities in Java. According to recent data from the Indonesia Investment Coordinating Board (IICB), the core of industrial investment in Indonesia-all industrial investment, not only foreign investment-is located in Java Island. Most of Indonesia's industrial establishments are located in Java Island. Furthermore, more than half of Indonesians dwell in Java, which means that Java Island is also a huge prospective market for final goods.

The basic preconditions for profitable greenfield investment are a ready supply of local labor and adequate infrastructure. Foreign firms often approach other foreign investors in their same industry or from their same country to find out local information. Some of the same foreign companies also cooperate with foreign industry colleagues (Tan \& Meyer, 2011). All of this is specific to the kind of industry and country of origin of the foreign investor. But when foreign investors gather information from the same sources and evaluate it in the same way, they are likely to reach similar decisions. Many

Table 1. FDI: Number of Projects and Total Investment, 1996-2017

\begin{tabular}{lrrrr}
\hline Region & $\begin{array}{c}\text { Projects } \\
\text { (Number) }\end{array}$ & $\begin{array}{c}\text { FDI Inflow } \\
\text { (Millions USD) }\end{array}$ & $\begin{array}{c}\text { Project } \\
\text { Share } \\
\text { (Percent) }\end{array}$ & $\begin{array}{r}\text { FDI Share } \\
\text { (Percent) }\end{array}$ \\
\hline Java & 73,268 & $2,819,185,225$ & 72.79 & 71.77 \\
Non-Java & 31,192 & $1,108,876,137$ & 27.21 & 28.23 \\
Total & 104,460 & $3,928,061,362$ & 100.00 & 100.00 \\
\hline
\end{tabular}

Source: BKPM, Calculated by the author. foreign investors in the same industry or from the same country may thus choose the same location for their greenfield investment. This implies a clustering of FDI but does not necessarily mean that agglomeration itself confers added profitability. It just means that different foreign investors have similar decision rules.

One of the main questions this paper aims to answer is whether agglomeration itself is a factor in the choice of FDI location in Indonesia. The strategy is to model the foreign investors' choices of location in a way that includes not only clustering of firms in the same industry or from the same county, but also includes characteristics of the locations. If after controlling for characteristics of each location related to the local labor force, infrastructure and so on, clustering still makes a choice of a location more likely, that would indicate that agglomeration itself is perceived by potential investors as having desirable effects.

\section{CONCEPT AND EMPIRICAL REVIEW Agglomeration Economics}

Agglomeration economies are increases in productivity that result from the concentration of economic activity in a particular area. Agglomeration economies are a form of economies of scale that arise at the industrial or social level, not the level of an individual firm. Some agglomeration economies are specific to a particular sector or industry. Others are general in the sense that they are realized by all firms operating in the same geographic area regardless of their industries.

Economic agglomeration refers to a decrease in production costs that comes about whenever economic activities are located in the same place. Marshall (1920) was the originator of the concept, which he dubbed "neighborhood effects of the localization of industry." Marshall pointed out that these effects amounted to an economy of scale at the industry level that arose as spillover effects from the location choices of individual firms each of which produced subject to constant returns to scale. There are four sources of beneficial spillovers ("neighborhood effects") that arise from agglomeration ("industrial localization").

1) Knowledge spillovers, where workers who work in different companies can exchange information because of the similarity of types of work.

2) Reduction of labor costs because the gathering of similar companies in an area will attract skilled workers, so the cost of finding labor becomes cheaper.

3) Lower prices of inputs because the greater the quantity of inputs demanded, the lower the cost 
of producing them because of economies of scale in producing inputs.

4) Lower prices because of increased competition.

Krugman (1998) based his "new economic geography" on two opposing forces that affect agglomeration, namely centripetal and centrifugal strength. Centripetal strength is a force that boosts agglomeration while centrifugal strength is the opposite. Centripetal strength explains why are there most commercial activities focused or gathered regionally. Most people in advanced and developing countries live in highly populated urban centers. Some industries (including services and banks) also gather geographically and these groupings are important aspects of specialization in international trade.

Economies from agglomeration arise from the concentration of the population and resulting concentration of economic activities. The advantages of spatial concentration that increase more in proportion than the increase in agglomeration are called agglomeration scale effects (Mills and Hamilton, 1989). Economic agglomeration is also related to the geographical proximity of economic activities. An economic agglomeration is a form of positive externality in production which is one of the factors causing the growth of cities (Giovannetti, 2003).

The economists Ohlin \& Hoover (1937) made a distinction between 'urbanization' economies and 'localization' economies. Urbanization economies are related to the advantage for all industries in the same location as a consequence of the magnitude of the economic scale (population, income, output, and prosperity) of that location. Localization economies are related to the advantages to companies in the same manufacturing sector that gather from colocation (Bekele \& Jackson, 2006).

The industry will benefit from the existence of localization economies and urbanization economies, depending upon the size of firms, the sort of industry, and how innovative the industry. Whether industrial progress benefits from agglomeration is highly dependent on the ability of the industry to adjust to changing demand and supply conditions (Villamil, 2010).

The general reality that occurs in the world is that newly developed industries usually choose to establish themselves in large cities, where the industry can take advantage of the rapid population growth and population demand. The large industries are concentrated in smaller regions or cities because the cost of density and labor is low and savings in localization are very important (Malmberg, et al., 2000).
Agglomeration occurs for several reasons. First is the factor of proximity to input providers and to consumers as the target market, which reduces transportation costs. The second factor is that industries which are located in the industrial group area will be more profitable than if they were located outside the grouping area. The advantage gained is the productivity of capital and labor use. These advantages come about because of the greater competition among input suppliers and because of access to information (Puga \& Duranton, 2000).

\section{Localization Economies}

Localization economies arise when an increase in the total output of all firms in a particular industry results in a decrease in the cost structure in that location. Economies due to this localization are external to the company but are internal to the industry.

Localization economies mean that production costs of individual company's decline when the output of the local industry increases. Some reasons why localization will increase productivity are:

1) Labor costs decrease in certain industrial areas when workers with the expertise needed by the industry gather and facilitate the finding of workers by reducing search costs.

2) Information relating to product demand (market conditions) or technological developments in the industry are easily obtained by every member of the local industry.

3) Proximity to input providers and consumers reduces transportation costs.

With the grouping of industries in the same area, it will be more profitable for entrants to also join that area. The advantage gained is the increased productivity of capital and labor (Rosenthal \& Strange, 2001).

\section{Urbanization Economies}

Urbanization economies are the strongest benefits that are external to any one industry because they promote regional economic growth. The inclusion of economies element due to agglomeration into the production function causes an increase in input use as a result of which output will be driven up with a higher rate of increase than the input itself so that economies due to agglomeration will have a positive impact on regional growth.

Urbanization economies ameliorate problems that arise in a city by increasing the wages for managers and other skilled workers and encouraging companies to choose locations outside the main city. As a result, the land price rises in real terms because 
the amount of land does not increase. The big cities also cause negative externalities, which are often associated with environmental pollution (Ellison, et al., 2010).

Zipf's law for cities-that the populations of the cities in a nation are inversely proportional to their ranks by population-is thought to reflect spatial production processes. The process of urbanization on a global scale can give rise to mega-cities (Gabaix, 1999). There are strengths in the process of agglomeration that affect the growth and development of cities, namely (1) the power that causes cities to become large by drawing industry into cities, has a positive impact on the specialization of production and the development of industrialization, and (2) agglomeration can reduce shipping costs, meaning that the cost of goods becomes lower if more companies are located in the same city, resulting in lower freight costs. Urbanization economies occur if the company's production costs decrease when the total output of the entire city increases. Urbanization economies come from technological externalities between products, and the joint use of intermediate inputs by many industries. To put it another way, there are economies of scope in production (Abdelrahman \& Anas, 2006).

\section{Empirical Review}

The aim of this study is to measure the external effect on the choice of FDI location of different types of agglomeration. To identify these effects, it is necessary to control for other characteristics of each location that may also induce clustering of FDI. Clustering that is the result of foreign investors valuing the same location characteristics as one another, such as having an ample infrastructure, low wages and so on, is not evidence that agglomeration is an attractive feature. To accurately measure the effects of agglomeration itself on location choiceswhich is our main aim-we need a model that can also capture various other factors affecting location choices by foreign firms.

There are many papers relevant to this paper that is related to foreign direct investment. Kinoshita \& Campos (2003) examine the determinants of foreign investment in transition economies using data for 1990-1998. The determinants of foreign investment on which they focus include agglomeration, external liberalization, and the quality of bureaucracy. They find differences between CEE and CIS countries. The effect of agglomeration has more influence in $\mathrm{CIS}$ countries than in other countries. The non-CIS countries with more liberal trading regimes attract more foreign investment. CIS countries in which workers have legal skills and in which the rule of law is stronger also attract more foreign investment. The variables in the Kinoshita and Campos estimating equation include ones related to various motivations for foreign investment which they classify as market seeking, resource seeking, and efficiencyseeking. Market-seeking foreign investors are more interested in countries with larger local markets and fast-growing markets. Resource-seeking investors are attracted to countries that have abundant natural resources. Efficiency-seeking investors have a more geographical approach and aim to minimize transport costs. They also include variables related to economic and political risks. Government economic successes at curbing inflation and maintaining low fiscal deficits are also taken into account. Additional variables are related to business operating conditions (non-economic factors) such as bribery and time lost during transactions. Controlling for all these various factors enables more precise estimation of the effects of agglomeration, the positive externalities that arise from the presence of knowledge spillovers, specialized labor markets, and network suppliers. They find that these agglomeration effects are statistically significant but relatively small.

Sridhar \& Wan (2008) analyze the selection of industrial locations in cities in three countries, namely China, India, and Brazil, using a multinomial logit model. Data for more than 1,000 companies in 50 cities are taken from the World Bank ICS (2002). The industrial cities in these countries are grouped into three categories, namely small, medium and large cities. The authors estimate a multinomial logit regression equation where the dependent variable is the choice of location of each company between small cities, medium cities, and large cities. Independent variables include the availability of natural resource inputs, government and company relations such as labor regulations, and company levels data such as size, number of workers, export status and company efficiency. Infrastructure variables show city characteristics such as electricity costs, the existence of asphalt roads and telephones.

The results show that capital cities are no longer attractive locations for foreign investment in China, India, and Brazil-the capitol dummy has a negative coefficient. Other variables also matter for investment location choice. Availability of inputs, the number of workers and the existence of labor regulations show the same results in China and India, which are positive for inputs and negative for labor regulations. Different results were obtained in the selection of industrial sites in Brazil where the existence of labor regulations had a positive effect while inputs/resources showed a negative influence on the selection of industrial sites. 
Popescu (2013) identifies the factors that attract newly established companies with foreign capital at the regional level in Romania. His analysis uses a nested logit model. The result confirms that FDI is located mostly in regions where other foreign companies have also chosen to invest and are successful in their business activity, but not necessarily where all firms (foreign and domestic) have the most developed activities. He also finds that investors prefer regions with higher net wages, which he includes as a proxy for purchasing power which capture local demand, and which seems to be a more important factor than the higher labor cost associated with higher net wages. Regional GDP has an insignificant effect.

Vide (2014) investigates FDI location decision factors of Austrian and German firms in Brazilian regions. He uses a multinomial nested logit model to show that FDI-specific country agglomeration (investor-nation), industry-specific sector, labor quality, and physical infrastructure were the important FDI location decision factors for German and Austrian firms in Brazil. Otherwise, the population share that proxies market demand, industry density, and urban density were not significant.

More relevant to the focus of this research, a number of empirical surveys use conditional logit models to investigate the determinants FDI location. Hilber \& Voicu (2010) exploit FDI inflows to Romania after the revolution in 1989, to analyze which factors affect the location decisions of foreign direct investors. They estimate a conditional logit function using micro-level data of companies to investigate several types of agglomeration. They find that the economic externality of service sector agglomeration was a major factor in the location decision of FDI. An increase in the number of workers in the service sector by 10 percent makes the average of 11.9 Romanian regions more attractive to foreign investment. Factors relevant to FDI location decisions include input prices (land, labor, and capital), market demand and infrastructure availability.

\section{METHOD}

The aim of this study is to measure the external effect on the choice of FDI location of different types of agglomeration. To identify these effects, it is necessary to control for other characteristics of each location that may also induce clustering of FDI. Clustering that is the result of foreign investors valuing the same location characteristics as one another, such as having an ample infrastructure, low wages and so on, is not evidence that agglomeration is an attractive feature. To accurately measure the effects of agglomeration itself on location choices- which is our main aim-we need a model that can also capture various other factors affecting location choices by foreign firms.

Regarding to the empirical studies, It was decided to put the main focus of the empirical research on a qualitative research method, which would be a conditional logit model (CLM), Multinomial Logit Model (MLM), and Nested Logit Model (NLM) derived from a discrete choice model (DCM) developed by McFadden (1973). A Discrete Choice Model has been widely used to examine FDI location choice factor (Tan \& Meyer, 2011; Vide, 2014). The Multinomial Logit Model adopts certain characteristics in its behavior from the Conditional Logit Model - the competing behavior between investment region's investment attractiveness will affect the total number of firms investing. Taking into account the different investment probablility estimations of the different models, it was decided that the MLM represent the middle way and the appropriate choice of the quantitative research method.

The location decision of foreign firms are modeled using a multinomial logit equation, where the dependent variable is the location chosen by each investor. This study covers 23 possible location choices. These locations are the counties in Java Island which have attracted foreign plants during the period of observation, 2013-2017. Following the method employed in earlier studies, such as Du, et al., (2008) and Vide (2014) this study exploits Mc Fadden's (1974) result that logit choice probabilities are derived from individual maximization decisions if unobserved heterogeneity takes the appropriate form. We assume that each investor chooses the location that would give it the highest profit. The location decision $Y_{i j}$ will be 1 if the foreign firm $i$ chooses alternative $j$, and $Y_{i j}$ will be 0 if the foreign firm $i$ does not choose alternative $j$. The foreign firms in the sample started operations between 2013 and 2017 and choose from among twentythree alternative locations, namely $j=1,2 \ldots, 23$. The investor $i$, if it locates in region $j$, will derive a profit of $\pi_{i i}$. These profit expectations are influenced by $\alpha_{j}$ which is a constant that captures unobserved characteristics of county j (specific endowment effect) that can determine the attractiveness of this county to foreign investors. A set of independent variables $Z$ represents the observed characteristics of individual companies $i$ and alternative choices $j$. A random disturbance $\varepsilon_{\mathrm{ij}}$ is presumed to follow the extreme value distribution, which is the basic underlying premise of the multinomial logit specification. More formally,

$$
\pi_{i j}=\alpha_{i j} \beta_{i j}+\varepsilon_{i j}
$$


Where $b$ is a vector of coefficients to be estimated, indicating the marginal effect of each observed variable on the profitability of each location to each company. The vector $X_{i j}$ includes variables: FDIAgglo ${ }_{i \gamma^{\prime}}$ DDIAgglo ${ }_{i j^{\prime}}$ ServAgglo $_{i j^{\prime}} R G D P_{i{ }^{\prime}}$ RegMinWage $_{i j^{\prime}}$ HiEduc $_{i j^{\prime}}$ RoadDens $_{i j^{\prime}}$ PopDens ${ }_{i j^{\prime}}$ Pop $_{i j^{\prime}}$.

$$
\begin{aligned}
\pi_{\mathrm{ij}}= & \alpha_{\mathrm{j}}+\beta_{1} \text { FDIAgglo }_{\mathrm{ij}}+\beta_{2} \text { DDIAgglo }_{\mathrm{ij}}+\beta_{3} \text { ServAgglo }_{\mathrm{ij}}+ \\
& \beta_{4} \text { RGDP }_{\mathrm{ij}}+\beta_{5} \text { RegMinWage }_{\mathrm{ij}}+\beta_{6} \text { HiEduc }_{\mathrm{ij}}+ \\
& \beta_{7} \text { RoadDens }_{\mathrm{ij}}+\beta_{8} \text { PopDens }_{\mathrm{ij}}+\beta_{9} \text { Pop }_{\mathrm{ij}}+\varepsilon_{\mathrm{ij}} . .(2)
\end{aligned}
$$

Alternative $j$ will be preferred by investor $i$ (meaning that $Y_{i j}$ has value 1 ) if alternative $j$ gives the highest profit of any in the choice set. The profit of $i$ from each possible choice $j$ is a random variable because, as written, it depends on $\varepsilon_{i j}$ which is a random variable. The probability that option $j$ has the highest profit of any in the choice set-that is, the probability that $i$ chooses $j$-is $P_{i j}$

$$
\mathrm{P}_{\mathrm{ij}}=\mathrm{P}\left(\mathrm{Y}_{\mathrm{ij}}=1\right)=\mathrm{P}\left(\pi_{\mathrm{ij}}>\pi_{\mathrm{ik}}\right) \text {, for any } k, k \neq j,
$$

The simplified model:

$$
\begin{aligned}
Z_{i j}= & \alpha_{j}+\beta_{1} \text { FDIAgglo }_{i j}+\beta_{2} \text { DDIAgglo }_{i j}+\beta_{3} \text { ServAgglo }_{i j}+ \\
& \beta_{4} \text { RGDP }_{i j}+\beta_{5} \text { RegMinWage }_{i j}+\beta_{6} \text { HiEduc }_{i j}+ \\
& \beta_{7} \text { RoadDens }_{i j}+\beta_{8} \text { PopDens }_{i j}+\beta_{9} \text { Pop }_{i j}+\varepsilon_{i j} . .(4)
\end{aligned}
$$

The above equation expresses the conditional logit formulation. If the error term $\varepsilon_{i j}$ follows the Weibull distribution (also called 'standard type I extreme value distribution') the probability of firm i to choose alternative location $j$ can be explained by:

$$
\begin{aligned}
& P_{i j}=\frac{\exp \left(Z_{i j}\right)}{\operatorname{\sum exp}\left(Z_{i j}\right)} \ldots \\
& \text { Or, equivalently } \\
& \ln \frac{P_{i j}}{1-P_{i j}}=Z_{i j}
\end{aligned}
$$

There are three possible cases in the interpretation of this log odds ratio (called 'logit'), including:

a. If the log odds ratio is $>1$, then a change in $Z$ 1 unit will increase the odds of choosing $j$ by $B$ times. In this case, $Z_{i j}$ has a positive effect on decision $j$.

b. If the log odds ratio $=1$, then a change in $Z_{i j}$ by 1 unit will not affect the odds of $j$ being chosen.

c. If the log odds ratio is $<1$, then a change in $Z_{i j}$ by 1 unit will decrease the odds of choosing $j$ by $b$ times. In this case, $Z_{i j}$ has a negative relationship to the decision $j$.

\section{Data}

To estimate the model outlined above, data were obtained from three of Indonesia's government agencies, and are described in the following.

\section{a. Dependent Variable}

The locations of new foreign-owned manufacturing establishments identify the decisions of foreign firms to choose from among a set of possible locations in Indonesia one particular location in which to directly invest. Thus, the dependent variable in this study is the county location of FDI in Indonesia in Java Island, which is the location decision variable $\left(Y_{i j}\right)$. The location decision will be 1 if the company $i$ chooses alternative $j$, and $Y_{i j}$ will be 0 if the company $i$ does not choose alternative $j$. Firms that have just started operations in 2013 to 2017 are faced with 23 alternative locations, namely $j=1, \ldots, 23$.

These observations come from the micro-level data of the Indonesia Investment Coordinating Board (BKPM). Based on Investment Law No. 25 of 2007, for each new FDI project must fulfill the minimum of Rp10 billion (USD73 million). The data of new foreign-owned firms are taken from 2013 to 2017, with around 3,143 new foreign manufacturing establishments. The observations for this study are limited to five dominant industrial sub-sectors: food, machinery, transportation, chemical, and textile industries. The sample includes observations on 1,993 instances of FDI in 23 counties in Java Island.

\section{b. Other Location Characteristics}

The estimating equation of this paper also includes location-specific variables other than agglomeration related ones. The regional gross domestic product (RGDP) is one such variable. The RGDP which proxy the local market is a likely determinant of the profitability of FDI. The big number of regional GDP makes a region more attractive for investors because a huge market provides more new opportunities to sell goods and services. Data on regional GDP was taken from Statistics Indonesia. RGDP for each county in 2013-2017 is the variable included in the regression. Greater RGDP in a county indicates the availability of a large market. I expect that the variable would have a positive relationship with the probability of FDI.

Another location characteristic that matters for FDI is the general level of wages. Higher wages imply a higher cost of production and lower profit. For our purpose, we need a variable that reflects regional variation in wages unrelated to variation in labor quality, that is not reflecting regional variation in the level of education or skills. This study uses the average regional minimum wage rate, taken from the Ministry of Manpower and Transmigration. Other 
authors have used legal minimum wage as a variable in explaining regional variation in choice of FDI location (Cheng \& Kwan, 2000; Sharma \& Bandara, 2010). It is my belief that regional variation in the legal minimum wage in Indonesia is a reasonable proxy for variation in the general level of wages. A higher minimum wage is a correlate of generally higher wages. All else the same, investors would expect lower profit if wages are higher. We expect that the regional minimum wage has a negative effect on foreign investment.

The next variable is the labor quality. This study proxy for the quality of labor force in a region is the fraction of the labor force that has completed senior high and vocational senior high schools (secondary education) or achieved undergraduate education. According to Statistics Indonesia, the labor force is defined as the population aged 15 years or over who are working or who are looking for work. I expect that labor quality has a positive effect on FDI inflows.

Another location characteristic is infrastructure. Infrastructure includes both public and private sector services and facilities that provide transportation networks, water, and power. Infrastructure includes roads, railways, water supply, electricity, airports, or water-ports. This study uses the log of road density as the correlate of infrastructure. Here, road density is defined as the total of national, provincial and county roads divided by the county area.

The last location characteristic is population density. Population density is a proxy for industrial land costs. This variable can capture land costs because greater population density means that more plants and residential users are competing to use land and bidding up its market price. This variable is expected to have a negative effect on attracting FDI inflows (Bartik, 1985).

\section{RESULTS AND DISCUSSION}

Table 2 shows empirical estimates of the multinomial logit model for explaining the probability of choosing a particular county in Java Island as a location for FDI, 2013 to 2017. Not all the agglomeration coefficients are positive as had been expected. FDI and DDI agglomeration show positive and significant effects while services agglomeration shows no significant impact. This means that the FDI location choices in Java Island are affected by the previous agglomeration of both foreign and domestic firms in the same industry. On the other hand, services agglomeration which captures the availability of services and accessibility to the business activity has no effect on the choice of location of foreign investment in Java. Based on those estimation results, some but not all kinds of
Table 2. Estimation Results

\begin{tabular}{|c|c|c|}
\hline Variable & Coef $\boldsymbol{B}_{i}$ & $\begin{array}{c}\text { Scalar Effect of A One-Unit } \\
\text { Change in the Variable on } \\
\text { The Odds of Choosing A } \\
\text { Location }\left(\mathrm{e}^{6 \mathrm{i}}\right)\end{array}$ \\
\hline $\begin{array}{l}\text { FDI } \\
\text { agglomeration }\end{array}$ & $\begin{array}{l}0.0041^{* * * *} \\
(27.64)\end{array}$ & $1.0041^{* * *}$ \\
\hline $\begin{array}{l}\text { DDI } \\
\text { agglomeration }\end{array}$ & $\begin{array}{l}0.0072 * * * \\
(13.71)\end{array}$ & $1.0072 * * *$ \\
\hline $\begin{array}{l}\text { Services } \\
\text { agglomeration }\end{array}$ & $\begin{array}{r}0.5158 \\
(1.43)\end{array}$ & 1.6750 \\
\hline RGDP & $\begin{array}{r}-0.0654 \\
(-0.72)\end{array}$ & 0.9367 \\
\hline $\begin{array}{l}\text { Regional } \\
\text { minimum wage }\end{array}$ & $\begin{array}{l}0.8797 * * * \\
(10.97)\end{array}$ & $2.4101 * * *$ \\
\hline Labor quality & $\begin{array}{l}-1.5640 * * \\
(-2.63)\end{array}$ & $0.2093 * * *$ \\
\hline Road density & $\begin{array}{l}0.1774 * * * \\
(9.93)\end{array}$ & $1.1941^{* * *}$ \\
\hline $\begin{array}{l}\text { Population } \\
\text { density }\end{array}$ & $\begin{array}{l}-0.5968 * * * \\
(-6.78)\end{array}$ & $0.5506^{* * *}$ \\
\hline $\begin{array}{l}\text { Population } \\
\text { (Inpop) }\end{array}$ & $\begin{array}{r}-0.1744 \\
(0.53)\end{array}$ & 0.8400 \\
\hline
\end{tabular}

Note: Figures in parentheses are robust standard errors.

*** denotes 1 percent significance level.

** denotes 5 percent significance level.

* denotes 10 percent significance level.

Source: author (2019).

agglomeration have a positive impact on attracting FDI.

Next, we focus on the variables other than ones related to agglomeration. Other location characteristics that significantly affect the decision of FDI location are road density and population density. Regional GDP does not have a statistically significant effect. Perhaps, high regional GDP does not matter to the export-oriented manufacturing investors, because their products are not sold in the local market (Belkhodja, et al., 2017). The positive sign of road density indicates that any increase in road density will increase the probability that a county will be selected as a location of investment. In contrast, the negative sign of population density shows that higher population density decreases the probability of FDI. That might be because of the higher price of land in an area if the location is getting more populated (Bartik, 1985).

Regional minimum wage and labor quality are statistically significant but have the opposite signs to what this study had expected. For the regional minimum wage, the positive sign means a higher regional minimum wage in a county will attract more new FDI. Wage rates alone do not determine FDI. Counties with high wage rates can still attract high tech investment. But the negative sign on labor 
Table 3. Estimation Results by Each Sub-Sectors

\begin{tabular}{|c|c|c|c|c|c|}
\hline Variable & $\begin{array}{l}\text { Food } \\
\text { Coef } B\end{array}$ & $\begin{array}{l}\text { Machinery } \\
\text { Coef } b\end{array}$ & $\begin{array}{l}\text { Motor Vehichle } \\
\text { Coef } B\end{array}$ & $\begin{array}{c}\text { Chemical } \\
\text { Coef } B\end{array}$ & $\begin{array}{l}\text { Textile } \\
\text { Coef } B\end{array}$ \\
\hline FDI agglomeration & $\begin{array}{c}0.0167^{* * *} \\
(4.91)\end{array}$ & $\begin{array}{l}0.0032^{* * *} \\
(5.67)\end{array}$ & $\begin{array}{r}0.0019 \\
(1.23)\end{array}$ & $\begin{array}{l}0.0037^{* * *} \\
(2.93)\end{array}$ & $\begin{array}{l}0.0198^{* * *} \\
(10.48)\end{array}$ \\
\hline DDI agglomeration & $\begin{array}{r}-0.0017 \\
(-0.65)\end{array}$ & $\begin{array}{r}-0.0071 \\
(-0.87) \\
\end{array}$ & $\begin{array}{l}0.0492^{* * *} \\
(3.52)\end{array}$ & $\begin{array}{l}0.0050^{* * *} \\
(2.71)\end{array}$ & $\begin{array}{r}-0.0006 \\
(-0.52) \\
\end{array}$ \\
\hline Services agglomeration & $\begin{array}{r}-0.4054 \\
(-0.39)\end{array}$ & $\begin{array}{l}-3.3030 * * * \\
(-3.04)\end{array}$ & $\begin{array}{r}-0.4160 \\
(-0.15)\end{array}$ & $\begin{array}{r}0.9050 \\
(1.33)\end{array}$ & $\begin{array}{l}-1.9383^{* * *} \\
(-2.98)\end{array}$ \\
\hline RGDP & $\begin{array}{r}0.1177 \\
(0.43) \\
\end{array}$ & $\begin{array}{l}0.5519 * * \\
(2.07)\end{array}$ & $\begin{array}{c}-1.0270 * \\
(-1.70)\end{array}$ & $\begin{array}{l}0.5354 * * * \\
(6.56)\end{array}$ & $\begin{array}{c}0.2973^{*} \\
(1.70)\end{array}$ \\
\hline Regional minimum wage & $\begin{array}{r}-0.0773 \\
(-0.38) \\
\end{array}$ & $\begin{array}{l}1.4738^{* * * *} \\
(7.55)\end{array}$ & $\begin{array}{c}3.4849 * * * \\
(6.53) \\
\end{array}$ & $\begin{array}{l}1.3084^{* * *} \\
(6.47)\end{array}$ & $\begin{array}{c}-0.2767^{*} \\
(-1.93)\end{array}$ \\
\hline Labor quality & $\begin{array}{r}0.4996 \\
(1.17) \\
\end{array}$ & $\begin{array}{r}0.2132 \\
(0.44) \\
\end{array}$ & $\begin{array}{r}0.0400 \\
(0.07) \\
\end{array}$ & $\begin{array}{r}0.0795 \\
(0.20) \\
\end{array}$ & $\begin{array}{r}-0.1061 \\
(-0.39) \\
\end{array}$ \\
\hline Road density & $\begin{array}{r}-0.0358 \\
(-0.68) \\
\end{array}$ & $\begin{array}{r}0.0314 \\
(0.66) \\
\end{array}$ & $\begin{array}{l}0.6221^{* * *} \\
(5.47)\end{array}$ & $\begin{array}{r}-0.0122 \\
(-0.36) \\
\end{array}$ & $\begin{array}{c}0.1657^{* * *} \\
(3.92)\end{array}$ \\
\hline Population density & $\begin{array}{r}0.1136 \\
(0.41) \\
\end{array}$ & $\begin{array}{r}-0.0219 \\
(-0.09) \\
\end{array}$ & $\begin{array}{l}-1.2149 * * * \\
(-2.68)\end{array}$ & $\begin{array}{r}-0.3062 \\
(-1.47) \\
\end{array}$ & $\begin{array}{r}-0.0444 \\
(0.21) \\
\end{array}$ \\
\hline Population & $\begin{array}{r}0.4907 \\
(0.53)\end{array}$ & $\begin{array}{l}3.2779 * * * \\
(3.25)\end{array}$ & $\begin{array}{r}-0.0882 \\
(-0.03)\end{array}$ & $\begin{array}{r}-0.7301 \\
(-1.14)\end{array}$ & $\begin{array}{l}1.6578 * * * \\
(2.96)\end{array}$ \\
\hline
\end{tabular}

Note: Figures in parentheses are robust standard errors.

*** denotes 1 percent significance level.

** denotes 5 percent significance level.

* denotes 10 percent significance level.

Source: author (2019).

quality indicates that any increase in the portion of the labor force with higher education will reduce the probability of a county being chosen by investors.

The higher minimum wage means a greater supply of unskilled workers to foreign firms. The foreign firms are hiring low-skilled workers and yet pay more than the minimum wage because they have to pay a compensating differential more than the domestic employers. It means the minimum wage is less binding on them than on domestic firms. And it might be the minimum wage increases the supply of low skilled workers to foreign firms. This result is in contrast to the existing literature which argues that foreign firms are reluctant to invest in rural areas because the low wages or high labor quality are outweighed by other disadvantages, such as lack of infrastructure, poor transport links, and absence of agglomeration economies. Wage rates or labor quality alone does not determine FDI location decisions. Counties with high wage rates or low quality of labor force can still attract high tech investment (Pettinger, 2017).

We next turn to the separate results for each sub-sector, shown in Table 3 Because the coefficient estimates differ across sub-sectors, we might think that the coefficient estimates for the pooled sample are misleading or biased. Thus it might be better to be more focused on interpretation by each sub-sector.
There are some differences across sectors in the estimated agglomeration effects. We first address the impacts of the agglomeration of foreign-owned companies in each specific industry sector. These are evaluated as the share of companies in a specified sector in each district. The estimated parameters for all five sub-sectors are positive and statistically significant for four of the five sub-sector industries (at the one percent level). It indicates that the agglomeration of sector-specific foreign-owned firms has a significant effect on company location choices of companies in a majority of industries. It also means FDI agglomeration in all sub-sectors has a strong influence in attracting foreign firms to locate in a county.

Domestic firm agglomeration only has a significant positive effect in the motor vehicle and chemical sectors. It may be that in these sub-sectors, foreign-owned and domestic companies display similar networking behavior. They build connections with domestic companies from whom they purchase inputs or even engage in joint production. Guimaraes, et al. (2000) find similarities between FDI and DDI companies. Both engage in outsourcing (joint production), joint equipment and input purchases, marketing, after-sales services, and Research and development. 
Table 4. Marginal Effects by Each Sub-Sectors

\begin{tabular}{|c|c|c|c|c|c|}
\hline Variable & $\begin{array}{c}\text { Food } \\
e^{6 i}\end{array}$ & $\begin{array}{c}\text { Machinery } \\
\mathbf{e}^{6 \mathrm{i}}\end{array}$ & $\begin{array}{c}\text { Motor Vehichle } \\
\mathrm{e}^{6 \mathrm{i}}\end{array}$ & $\begin{array}{c}\text { Chemical } \\
\qquad \mathrm{e}^{6 \mathrm{i}}\end{array}$ & $\begin{array}{c}\text { Textile } \\
\mathrm{e}^{6 \mathrm{i}}\end{array}$ \\
\hline FDI agglomeration & $1.0169 * * *$ & $1.0032 * * *$ & 1.0019 & $1.0037^{* * *}$ & $1.0201 * * *$ \\
\hline DDI agglomeration & 0.9982 & 0.9929 & $1.0504^{* * *}$ & $1.0050 * * *$ & 0.9994 \\
\hline Services agglomeration & 0.6667 & $0.0368 * * *$ & 0.6597 & 2.4721 & $0.1439 * * *$ \\
\hline RGDP & 1.1249 & $1.7365^{* *}$ & $0.3581 *$ & $1.7081^{* * *}$ & $1.3463 *$ \\
\hline Regional minimum wage & 0.9256 & $4.3661 * * *$ & $32.6201 * * *$ & $3.7004 * * *$ & $0.7583^{*}$ \\
\hline Labor quality & 1.6480 & 1.2376 & 1.0409 & 1.0827 & 0.8993 \\
\hline Road density & 0.9649 & 1.0319 & $1.8629 * * *$ & 0.9879 & $1.1802 * * *$ \\
\hline Population density & 1.1203 & 0.9783 & $0.2967 * * *$ & 0.7362 & 0.9565 \\
\hline Population & 1.6335 & $26.5191 * * *$ & 0.9155 & 0.4819 & $5.2476 * * *$ \\
\hline
\end{tabular}

Notes: Scalar effect of one-unit change in the variable on the odds of choosing a location $\left(\mathrm{e}^{6 \mathrm{i}}\right)$.

*** denotes 1 percent significance level.

** denotes 5 percent significance level.

* denotes 10 percent significance level.

Source: author (2019)

The findings for the regional gross domestic product (RGDP) indicate that for the majority of the industrial sectors, proximity to the domestic market increases the potential profit and hence affects location decisions at the company level. That is important for the machinery, chemical, and textile industries. However, different effects are seen in the motor vehicle industry with a 10 percent significance level, which means that local market demand is not a determining factor, because their final products might be not for sale in the domestic market but for export abroad. Some automotive products are distributed to the capital city because there are better service facilities such as trade and marketing services.

The negative sign of the regional minimum wage (10 percent significance level) is notable in food manufacturing. It might be because most FDI in the food industry is attracted to counties which have a great number of people (positive effect of the population) and a low regional minimum wage. Foreign-owned companies in the food industry are focused on the cost of labor and the distribution of products. However, a different result than was expected is shown for regional minimum wage in other sectors which is highly significant in the machinery, motor-vehicle and industries. The positive sign of regional labor minimum wage might indicate that new foreign-owned companies in these sectors are focused on location that are already developed and have many foreign and domestic participants (FDI and DDI agglomeration). The agglomeration variables have strongest effect in attracting new FDI in these specific sub-sectors, compared to labor cost factors. Another reason that was concluded by Popescu (2013) is that higher wages indicate not only higher cost but also greater purchasing power. Thus, local demand may be a more important factor in attracting FDI than low cost.

Road density-the proxy variable for infrastructure-only matters for the motor-vehicle and textile industries. It might be the road density variable is not a good enough proxy for infrastructure. On the other hand, population density measures the amount of developed industrial land that is available in each district. This variable is only significant in the motor-vehicle industry sub-sector. The negative sign shows the greater the population density, the less new FDI is attracted, due to the high cost of land.

Now, turning to the analysis of the results of the estimation. Unlike ordinary linear regression models in which coefficients can be directly interpreted as partial derivatives, the coefficients of the logit regression require further interpretation. Marginal effects are changes in the odds of a location being chosen in response to a small change in any of the location's characteristics. Marginal effects are calculated from the coefficient of variables that are significant at the level of 1 percent and 5 percent. Below is a table of calculation of marginal effects that are calculated by computing the exponential power of the estimated coefficients. These represent the scale effect on the odds of choice of a location associated with a one-unit change in the corresponding independent variable. The effect of this on the probability of the location being chosen depend upon the assumed initial probability, before the one-unit change in characteristic. Note that the 'odds' of an event occurring refer to its probability of occurring relative to the probability of it's not occurring. So for instance, two-to-one odds mean a two-thirds probability. 
The findings for foreign-owned firm's agglomeration (FDI agglomeration) show that the existence of foreign plants in a specific sector will influence location decisions at the firm level. Based on the table of marginal effects in Table 4, the estimated odds ratio is positive in four sectorsfood, machinery, chemical, and textile. The marginal effect of FDI agglomeration means that when every one foreign firm in the food sector or textile sector increases, thus it will increase the odds of the county being chosen by 1.02 times.

This study estimates also the effect of domestic agglomeration, measured by the total of domestic firms in specific sub-sector industry. Domestic agglomeration is significant in influencing industry location in the motor-vehicle and chemical subsectors. The marginal effect shows every onedomestic-firm increase in the motor-vehicle and chemical industry in one region will increase its odds of attracting FDI by 1.05 times and 1.005 times, respectively. However, services agglomeration which is measured by the log of total tertiary sector employment shows a significant negative result in the machinery and textile industry. For example, in machinery, the odds ratio-0.04 means that a 10 percent increase in total labor in the tertiary sector, will be associated with an approximately 0.37 percent reduction in regional attractiveness or potential profitability. On the other hand, for example in the textile products, the odds ratio -0.14 means, that a 10 percent increase in services labor will be associated with a 1.43 percent reduction in regional attractiveness.

The scale of the domestic market is proxied by regional gross domestic product which means a region with good access to local markets is likely to increase demand for the company's products. The estimated odds ratio shows that regional GDP significantly influences location decisions of the four sub-sector industries. It is highly significant in the chemical subsector, which produces consumption products such as, soap, shampoo, and cosmetics. Every 10 percent increase in RGDP is associated with approximately 17 percent increase in regional attractiveness. In contrast, a negative impact is shown in the motorvehicle products industry with an odds ratio 0.36 . It means that a 10 percent increase in regional GDP will be associated with an approximately 3.5 percent reduction in regional attractiveness.

In terms of regional characteristics, labor cost can be a location decision factor. This study uses a regional minimum wage to proxy labor cost. The findings show that regional minimum wage is consistently negative but significant only in the textile industry. The odds ratio is 0.75 which means that one million rupiahs increase in the regional minimum wage will decrease a county's attractiveness by 0.75 times. However different effects are shown in other industries-machinery, motor-vehicle and chemical. This means a higher regional minimum wage attracts FDI. The higher regional minimum wage might be an attractive feature if it is binding on domestic rival employers of labor but not the foreign affiliates. By increasing the supply of labor to foreign affiliates it could actually reduce the wage the foreign affiliates had to pay. The quality of labor which is proxied by the level education of labor force has statistically insignificant results in attracting new foreign investors, in all five sub-sector industries.

Road density-the infrastructure variable-is defined as the length of road divided by area. This variable is only significant in the motor-vehicle and textile industries. The estimated odds ratio implies that a 10 percent increase in that measure makes the average Java Districts 18.62 percent more likely to attract a foreign investor in motor-vehicle firms and 11.80 percent in textile firms. On the other hand, population density which measures the density of population in each county is only significant in the motor-vehicle industry. Every 10 percent increase in population density will reduce the odds of a foreign investor choosing that region by 18.63 percent.

\section{CONCLUSION}

This study focused on Java Island in which most of the foreign-owned firms in Indonesia are located. Java Island has 119 counties and each has unique characteristics. FDI is distributed throughout Java Island. However, there are no previous studies analyzing how regional characteristics influence the location decisions of FDI into Indonesia. That is the contribution of this paper, an econometric analysis of the location of FDI across counties in Java Island.

The results show that each sector has different factors that affect the location choice of FDI. FDI agglomeration has a positive impact in all sub-sectors except motor-vehicles. However, domestic firms agglomeration has a significant positive impact in motor-vehicles while the DDI agglomeration variables have no significant impact on food, machinery, and textile sectors. The size of the domestic market has a positive and significant impact on FDI in the machinery, chemical, and textile sectors. The regional minimum wage has a negative impact on attracting FDI only in the textile industry, while in other sectors including machinery, motor-vehicles, and chemicals it has the same anomalous positive effect which is found in the pooled sample estimates. On the other hand, road density has a positive impact on the motor vehicles and the textile industry while the 
negative effect on population density only matters on the motor vehicles industry.

In order to realize the location decision of FDI, it necessary to consider alternative approaches that are reasonable for low density and rural regions, for example, mostly manufacturing activity has already focused in agglomerated area (Bekasi District and Karawang District) wherein this analysis the agglomeration factor is not so strong. Agglomeration economies in production (both foreign-owned firms and domestic firms) show a significant and positive but small impact. Other variables including facilities, and labor market conditions-anomalously in that a higher minimum wage and less educated workforce attract FDI-matter as much or more than agglomeration of production. Because the agglomeration effect is small, it means that agglomeration economies are not the determining factor in attracting FDI. The new foreign investors not only seek counties in which foreign or domestic plants have already located but also consider other things such as the density of roads and the availability of labor. As Foreign investors seek the availability of labor and density of roads, the government should consider to increase the infrastructure endowment and add more infrastructure for the least developed counties which might have limited payoffs in term of attracting initial foreign-owned companies. In addition, the higher regional minimum wage might be an attractive feature if it is binding on domestic rival employers of labor but not the foreign affiliates. This could well be the case if the reluctance to seek employment in a foreign affiliate gave rise to a compensating wage differential so that the market wages were generally higher at a foreign affiliate. Then a higher minimum wage would expand the supply of labor to the foreign affiliates and actually reduce the wage the foreign affiliates had to pay. This explanation is speculative but comports with the logic of economics. It merits further investigation.

Lastly, since 2004, Indonesia has implemented decentralization which emphasizes local political autonomy. However, this study did not include organizational factors such as institutional and political factors which may also influence the decision of FDI. Thus for the future studies, the relation between FDI location decision and local local government policy will need to be shown.

\section{REFERENCES}

\section{Journal and Working Paper}

Abdel-Rahman, H.M., \& Anas, A. (2003). Theories of system of cities. Department of Economics and Finance Working Papers, 1991-2006. Paper 2. University of New Orleans, New Orleans.

Bartik, T.J. (1985). Business location decisions in the united states: Estimates of the effects of unionization, taxes, and other characteristics of states. Journal of Business and Economic Statistics, 3(1), 14-22.

Bekele, G.W., \& Jackson, R.W. (2006). Theoretical perspectives on industry clusters. Research Paper 2006-5. Regional Research Institute, West Virginia University, West Virginia.

Belkhodja, O., Mohiuddin, M., \& Karuranga, E. (2017). The determinants of FDI location choice in China: A discrete-choice analysis. Applied Economics, 49(13). 1241-1254.

Cheng, L.K., \& Kwan, Y.K. (2000). What are the determinants of the location of foreign direct investment? The Chinese experience. Journal of International Economics, 51(2), 379-400.

Du, J., Lu, Y., \& Tao, Z. (2008). FDI location choice: Agglomeration vs institutions. International Journal of Finance and Economics, 13(1), 92-107.

Ellison, B.G., Glaeser, E.L., \& Kerr, W.R. (2010). What causes industry agglomeration? Evidence from coagglomeration patterns. American Economic Review, 100(3), 1195-1213.

Gabaix, X. (1999). Zipf's Law for cities: An explanation. The Quarterly Journal of Economics, 114(3), 739767.

Giovannetti, E. (2003). Economics of agglomeration: Cities, industrial location, and regional growth. The Economic Journal, 113(488), F395-F397.

Guimaraes, P., Figueiredo, O., \& Woodward, D. (2000). Agglomeration and the location of foreign direct. Journal or Urban Economics, 47, 115-135.

Kinoshita, Y., \& Campos, N.F. (2003). Why does FDI go where it goes? New evidence from the transition economies. William Davidson Institute Working Paper No. 573. University of Michigan Business School, Michigan. 
Malmberg, A., Malmberg, B., \& Lundequist, P. (2000). Agglomeration and firm performance: Economies of scale, localisation, and urbanisation among Swedish export firms. Environment and Planning A, 32(2), 305-321.

Popescu, R.G. (2013). The regional location decision of Foreign Direct Investments in Romania. Ekonomska Istrazivanja-Economic Research, 26(1), 33-48.

Puga, D., \& Duranton, G. (2000). Diversity and specialisation in cities: Why, where and when does it matter? Urban Studies, 37(3), 533-555.

Rosenthal, S.S., \& Strange, W.C. (2001). The determinants of agglomeration. Journal of Urban Economics, 50(2), 191-229.

Sharma, K., \& Bandara, Y. (2010). Trends, patterns and determinants of Australian Foreign Direct Investment. Journal of Economic Issues, 44(3), 661-676.
Tan, D., \& Meyer, K.E. (2011). Country of origin and industry FDI agglomeration of foreign investors in an emerging economy country-of-origin and industry FDI agglomeration of foreign investors in an emerging economy. Journal of International Business Studies, 42(4), 504-520.

Vide, R.K.-. (2014). Foreign Direct Investment Location choice factors: Some evidence for Brazil, 2(3), 424-440.

Villamil, J.C. (2010). How do agglomeration economies affect the development of cities? Revista de Economía del Caribe, 6, 95-112.

\section{Website}

Primadhyta, S. (2017, Feb 07). Tak cukup gantungkan nasib pertumbuhan ekonomi pada konsumsi. Accessed 12 May 2019 from https://www.cnnindonesia.com/ekono mi/20190207113806-532367107/tak-cukupgantungkan-nasib-pertumbuhan-ekonomipada-konsumsi. 